San Jose State University

SJSU ScholarWorks

Faculty Publications, Biological Sciences

Biological Sciences

May 2007

\title{
Dislodged But Not Dead: Survivorship of a High Intertidal Snail Following Wave Dislodgement
}

Luke P. Miller

Stanford University, luke.miller@sjsu.edu

Michael J. O'Donnell

Stanford University

Katharine J. Mach

Stanford University

Follow this and additional works at: https://scholarworks.sjsu.edu/biol_pub

Part of the Biology Commons

\section{Recommended Citation}

Luke P. Miller, Michael J. O'Donnell, and Katharine J. Mach. "Dislodged But Not Dead: Survivorship of a High Intertidal Snail Following Wave Dislodgement" Journal of the Marine Biological Association of the United Kingdom (2007): 735-739.

This Article is brought to you for free and open access by the Biological Sciences at SJSU ScholarWorks. It has been accepted for inclusion in Faculty Publications, Biological Sciences by an authorized administrator of SJSU ScholarWorks. For more information, please contact scholarworks@sjsu.edu. 
Running head: Littorine survival following dislodgement

\title{
Dislodged but not dead: survivorship of a high intertidal snail following wave dislodgement
}

\author{
Luke P. Miller ${ }^{1, *}$, Michael J. O’Donnel1 ${ }^{1,2}$, Katharine J. Mach ${ }^{1}$ \\ ${ }^{1}$ Hopkins Marine Station of Stanford University, Pacific Grove, CA, USA, $93950{ }^{2}$ Present address: \\ Marine Science Institute, University of California, Santa Barbara, Santa Barbara, CA, USA, 93106 \\ *corresponding author email: contact@lukemiller.org
}

\begin{abstract}
Waves breaking on rocky shorelines impart large forces on intertidal organisms, sometimes dislodging individuals. Dislodged individuals may be deposited in habitats that have a greater risk of predation or that prevent return to preferred regions on the shore. Thus, dislodgement is often assumed to be lethal. We experimentally dislodged Littorina keenae snails from high in the intertidal zone to test the likelihood of survival. Under a variety of wave conditions, we measured return rates to the high shore of 54$90 \%$. For this species, then, dislodgement is not equal to death. Snails showed a strong preference for returning to the approximate tidal height from which they were dislodged, but we found no evidence of widespread homing behavior back to the original site of dislodgement.
\end{abstract}

\section{INTRODUCTION}

Organisms living in the wave-swept intertidal zone risk dislodgement by wave action or by the activities of other organisms. Over the past several decades, biomechanics have explored the likelihood of dislodgement for many species, including macroalgae (Carrington, 1990; Gaylord et al., 1994; Blanchette, 1997), crustaceans (Lau and Martinez, 2003), and various molluscs (Denny, 1987, 1995; Denny and Blanchette, 2000; Carrington, 2002). For various species in different locations, it is possible to estimate the risk of dislodgement from the substratum under various wave conditions (Denny, 1995). However, the consequences of dislodgement for individuals are less predictable. For certain algae, breakage may function as a dispersal mechanism (Paine, 1988; Blanchette, 1997). For non-motile organisms such as barnacles, dislodgement 
causes substantial damage and is almost certainly fatal. For mobile grazers, such as gastropods, the consequences are less clear. While the dislodgement process itself is not necessarily fatal, displacement from preferred habitat exposes snails to various dangers. For example, displaced high intertidal zone snails face numerous predators in the low intertidal zone and may not be able to return to preferred locations high in the swash zone due to wave action or obstacles (Kent, 1981).

The morphologies of certain mobile grazers, notably the limpets - with a large area of foot in contact with the substratum - make dislodgement by waves or neighbors unlikely (Denny and Blanchette, 2000). Other gastropods, such as whelks, littorines, and turban snails, with a smaller foot area and larger shell area, bear greater risk of dislodgement. These species often find refuge amongst surrounding algae and sessile invertebrates, but this shelter is not perfect, and these organisms are occasionally confronted with wave forces stronger than their attachment strength (Menge, 1976; Kent, 1981; Boulding and Van Alstyne, 1993; Denny, 1995; Trussell, 1997). Investigators studying intertidal organisms have frequently assumed that wave dislodgement carries with it a high probability of mortality (Boulding and Van Alstyne, 1993; Denny, 1995; Trussell, 1997). In this study, we tested the likelihood of survival following wave dislodgement for an intertidal snail, Littorina keenae Rosewater.

Littorine snails living high on rocky shores are susceptible to dislodgement by waves. In the supralittoral zone, algae and other organisms provide little surrounding cover, leaving littorines exposed on the rock surface. Littorines are normally active while the rocks are submerged or wetted by splashing waves and spray (Bock and Johnson, 1967; Norton et al., 1990; Gochfeld and Minton, 2001; Pardo and Johnson, 2004). When the tide drops and rocks become dry -sometimes for days or weeks on the high shorelittorines are typically inactive. To preserve body water, many littorine species glue the lips of their shells to the substratum and withdraw the body and foot inside the shell, sealing the shell aperture with the operculum (Broekhuysen, 1940; Vermeij, 1971; Garrity, 1984; McMahon and Britton, 1985; Lang et al., 1998; Wada and Ito, 2000). This behavior allows them to hold their positions on the shore while conserving water and potentially reducing conduction of heat from the substratum to the body during hot periods. This behavior has also been speculated to increase the risk of dislodgement in 
the face of strong wave action or other disturbances due to the reduced tenacity of this attachment method compared to attachment via the foot (Bock and Johnson, 1967; Raffaelli and Hughes, 1978; Garrity, 1984; Lang et al., 1998; Wada and Ito, 2000).

During times of high tides and large waves, supralittoral rocks are sometimes swept by flows sufficient to cause dislodgement, regardless of whether the snails are withdrawn into their shells and attached with dried mucus, or if they have the foot extended and attached to the substratum (Raffaelli and Hughes, 1978; McQuaid, 1981; Underwood and McFadyen, 1983; Addy and Johnson, 2001). The fate of these dislodged snails is unknown. Predators such as crabs, fish, whelks, seastars and anemones are common in the low and mid intertidal zones and may feed on stray littorines (Bigler, 1964; Dayton, 1973; Menge, 1974; Boulding and Van Alstyne, 1993). In addition, wave action, if continuous and severe enough, may wash snails further into the low intertidal and subtidal regions, preventing them from moving up the shore. Movement up the shore has been demonstrated for several high intertidal snail species transplanted lower on the shore during low tide periods (Evans, 1961; Bock and Johnson, 1967; Gendron, 1977; Thain et al., 1985). However, whether snails knocked directly into waves during high tide ever return is unknown.

We experimentally dislodged marked snails during high tide in a manner consistent with wave-induced disturbance. Dislodgements occurred in a variety of wave conditions. Subsequently, we counted the surviving snails over the following month to determine if they survived dislodgement and exhibited directed movement back to the original sites from which they were removed. If L. keenae cannot survive displacement to the lower intertidal zone, we would expect to find few survivors following a disturbance event. If L. keenae are capable of navigating through the lower intertidal zone and returning to the upper intertidal zone, we would expect to find high return rates of snails to the high shore near the original sites of dislodgement.

\section{MATERIALS AND METHODS}

Dislodgement experiments with Littorina keenae were carried out on a waveexposed section of Mussel Point at Hopkins Marine Station (HMS) in Pacific Grove, CA $\left(36^{\circ} 37^{\prime} 18.00^{\prime} \mathrm{N}, 121^{\circ} 54^{\prime} 15.47^{\prime} \mathrm{W}\right)$. We selected three sites, spaced at a horizontal 
distance of approximately 10 meters, for collection of snails and later censuses. Each site consisted of a tall granite promontory rising out of the low and mid intertidal zone, typical of the high topographic relief of the shoreline at HMS (Figure 1). A relatively flat area of boulders and bedrock at a height of 0.5 to 1.5 meters above Mean Lower Low Water (MLLW, National Tidal Datum Epoch 1983-2001, Monterey, CA) extended beneath each granite promontory. The chosen sites are awash over their entire height during periods of high wave action.

At each of the three sites, for each of three experimental iterations, 50 adult $L$. keenae with shell length (tip of spire to farthest growing edge of the aperture) of at least 7 $\mathrm{mm}$ were collected. Snails were collected from a $1 \mathrm{~m}^{2}$ area on the rock face, approximately $3 \mathrm{~m}$ above MLLW at each site, and returned to the laboratory for tagging. Each shell was coated with brightly-colored acrylic nail polish to facilitate subsequent location in the field. We also affixed an individually numbered tag onto each shell using cyanoacrylate glue. A final coat of clear nail polish provided protection against abrasion and UV fading of the ink and colored nail polish. Tags were printed on plastic-based paper (HP ${ }^{\circledR}$ LaserJet tough paper, 5 mil thickness) in 6-point font. Tag dimensions were approximately $3 \mathrm{~mm}$ by $5 \mathrm{~mm}$, as small as possible in order to minimize added drag.

After marking the snails, we allowed the nail polish to dry for 3 hours and then kept the snails in flowing seawater aquaria overnight. Snails were judged unaffected by the painting and drying process if they attached to the sides of the aquaria and crawled out of the seawater, as unmanipulated L. keenae do. Two snails were removed from the experiment due to unresponsiveness.

To test for potential effects on survival due to the handling and marking of snails, we deployed groups of 25 control snails per site during the third deployment period. These snails were painted a different color than experimental snails, numbered with tags, and held over night, as with experimental snails.

Deployments took place on October 27, 2004, November 9, 2004, and February 22, 2005, during high tide. Offshore significant wave height $\left(\mathrm{H}_{\mathrm{s}}\right)$ on each of these dates was measured with a Seabird SBE 26 wave gauge located $50 \mathrm{~m}$ offshore from the sites at a depth of $12 \mathrm{~m}$. We transported snails to the site from which they were collected and dropped them into waves washing over the site. This action was meant to simulate snails 
being dislodged by wave impact, with no opportunity for quick reattachment before falling into the lower intertidal zone. Snails in the control group, deployed during February, 2005, were placed back in the $1 \mathrm{~m}^{2}$ high intertidal sites from which they had been collected and allowed to sit and reattach with their foot. Despite this care, two snails from the control groups were dropped into the low intertidal. Control snails were surveyed along with experimental snails, and their positions were noted. These control snails indicated the rate of natural dislodgement during the time of the study.

During the low tide following deployment and, conditions permitting, during subsequent daytime low tides, we located marked snails at each site. The search area consisted of the granite promontory and a horizontal area at the base, approximately $5 \mathrm{~m}$ along the shore to each side. Our search areas overlapped between sites, so that we searched a $30 \mathrm{~m}$ long section of the mid intertidal zone around the three sites, which encompassed the general directions in which wave action would be expected to deposit unattached snails. The mid intertidal zone around each site was primarily covered by the algae Mastocarpus papillatus Kützing. The high intertidal zone ( $1.5 \mathrm{~m}$ to $3 \mathrm{~m}$ above MLLW) around each site was covered by M. papillatus and the turf alga Endocladia muricata J. Agardh, with bare rock above the algae. We kept track of the approximate shore height of marked snails when they were found and noted snails that returned to the original site of collection.

Censuses of sites were carried out for a total of twenty person-minutes of searching per site, per day. Search time was fixed to enforce adequate search effort during inclement conditions. The searchers recorded tag numbers and regions (e.g. Mastocarpus zone, supralittoral zone) in which marked snails were found. Snails were not disturbed during these counts, except when they had to be removed from deep crevices to view tags. Removed snails were returned to the same spots in which they were found.

\section{RESULTS}

The three experimental deployments encompassed a range of wave conditions. The first deployment (Oct. 26 ${ }^{\text {th }}, 2004$ ) was carried out during a $+1.2 \mathrm{~m}$ high tide with 1.5 m significant wave height $\left(\mathrm{H}_{\mathrm{s}}\right)$. The second deployment (Nov. $8^{\text {th }}$, 2004) occurred during 
$\mathrm{a}+1.3 \mathrm{~m}$ high tide during a $0.59 \mathrm{~m} \mathrm{H}_{\mathrm{s}}$ swell. The third deployment (Feb. $\left.22^{\text {nd }}, 2005\right)$ was carried out during a $+1.3 \mathrm{~m}$ high tide with a $1.0 \mathrm{~m} \mathrm{H}_{\mathrm{s}}$ swell. The return rate of marked snails was high after all three deployment dates (Figure 2, Table 1). During the deployment with the largest waves $\left(1.5 \mathrm{~m} \mathrm{H}_{\mathrm{s}}\right), 85$ of the original 150 (56.7\%, three sites combined) were located over the subsequent four weeks. The second largest wave conditions, during February $\left(1.0 \mathrm{~m} \mathrm{H}_{\mathrm{s}}\right.$ ), yielded a return rate of $77.8 \%$ (116 out of 149 snails). The calmest wave conditions $\left(0.5 \mathrm{~m} \mathrm{H}_{\mathrm{s}}\right)$ produced a similar survival rate, 116 of 150 snails (77.3\%). Two additional snails from this group were found after the four-week trial period. When the number of returned snails at each site is compared across the three different wave heights, the effect of wave height is marginally non-significant (ANOVA, $\left.\mathrm{F}_{2,6}=4.512, \mathrm{df}=2, \mathrm{p}=0.064\right)$.

All of the experimental snails initially landed in the low to mid intertidal zones. Of the 317 dislodged snails found alive during the course of the three deployments, only 41 snails remained in the mid intertidal zone at the end of the experiment. All other snails crawled back to the bare rock of the high intertidal zone, past the Endocladia muricata zone.

Control snails had a high survival and recapture rate. By the second day of the deployment, 71 out of the original 74 control snails had been found. After three weeks 72 control snails had been found alive. No control snails were dislodged and found in the mid intertidal zone after the initial deployment.

A small number of marked snail shells were found inhabited by hermit crabs (Pagurus species). These snails may have landed in Anthopleura anemones during deployment or subsequent crawling, or been ingested by Pisaster ochraceus seastars, with intact shells being ejected after the snail bodies were consumed. Marked shells inhabited by hermit crabs were removed from the site. These shells were not included in the counts of total returned snails ( 5 after second deployment, 6 after third). Some shells, initially found alive following disturbance, were subsequently occupied by hermit crabs (1 after first deployment, 1 after second deployment and 3 after third deployment). None of the snails in the control group was ever found with a hermit crab inhabiting the shell. Snails killed before the end of the experimental period were not included in the final tally of surviving snails. 


\section{DISCUSSION}

Following large wave events at Hopkins Marine Station, we have observed large numbers of adult Littorina keenae in the low and mid intertidal zones, much lower on the shore than they are normally found, with fewer snails present high on the rock. In addition, one of us (L. Miller) has observed, with time-lapse video, L. keenae crawling from the low intertidal zone to the high intertidal zone in the days following large wave events.

The results of this study indicate that dislodgement of snails into the low and mid intertidal zones is not necessarily lethal for L. keenae. A substantial percentage (54-90\%) of the experimental snails in each trial returned to the high intertidal zone and assumed positions near their original shore height. Bock and Johnson (1967) found a similar response for $L$. keenae transplanted in a controlled manner during low tide to two sites lower on the shore at Bodega Head, CA. These snails presumably had time to attach to the substratum before waves returned with the incoming tide. The Bock and Johnson study was aimed at observing the movement of snails up or down the shore when displaced, and was not intended to measure potential survival rates following dislodgement by waves. We do not know the intensity of wave action during their experiments, but Bock and Johnson measured return rates to the high shore of approximately $73-80 \%$, rates similar to our findings.

We found no evidence of shell damage among the snails that were recaptured or damage to the shells that had been occupied by hermit crabs. There were no cracked or crushed shells, and the shell surfaces were not noticeably altered. It may be noted anecdotally that following natural disturbance events at this site, many L. keenae that return to the high shore have shells which have lost the normally pitted light-brown shell surface and instead have "polished" smooth shells surfaces with mottled coloration ranging from white to black. The mechanism for this polishing is unknown, but could be a result of abrasion by sediment during dislodgement or ingestion by a predator such as an anemone which does not result in digestion of the snail. We saw no evidence of this polishing for the snails used in this experiment.

Retention of marked control snails within the $1 \mathrm{~m}^{2}$ original sites of our experiment was high (92-100\%) at all sites. Movement of these control snails was 
limited, often confined to small movements within the $1 \mathrm{~m}^{2}$ area. We are confident that our marking procedure did not produce abnormal behavior or mortality, and that losses of snails in the treatment groups were due primarily to natural causes such as predation. Our measurements are conservative in that snails may have survived disturbance but been transported outside our census area; thus, survival may have been higher than we directly measured.

The area in which littorines were deployed consists of boulders and bedrock, which present substantial topographic relief. Snails had to crawl over complex topography to return to the high intertidal zone and may have used a variety of sensory cues to accomplish this directed movement (Evans, 1961; Warburton, 1973; Thain et al., 1985). Simple responses such as geotaxis and determination of water flow direction may be supplemented by more complex sensory processes such as vision. Littorines have image-forming eyes with relatively greater resolving capabilities than many other molluscs, which may allow them to pick out silhouettes of the high intertidal rocks rising above them and find their way back to the supralittoral zone (Newell, 1965; Hamilton and Winter, 1982; Thain et al., 1985; Seyer, 1992; Land and Nilsson, 2002).

Although an individual L. keenae may potentially sense its location within the general habitat of the intertidal zone, our results do not indicate any homing ability over long distances (several meters). Many marked snails returned to the high intertidal zone, but only $36 \%$ of the marked snails across all sites returned to the original $1 \mathrm{~m}^{2}$ site of collection. Littorine snails graze over wide areas along the shore and show some seasonality in their preferred shore height, so we did not expect a strong impetus for return to the exact site of collection (Gowanloch and Hayes, 1926; Gendron, 1977; Hamilton, 1978; Petraitis, 1982; Warner, 2001). Though L. keenae individuals cannot always maintain their positions high on the shore while being buffeted by large waves, we have demonstrated that a high percentage of snails survive dislodgement and return to the shore height previously occupied. Thus, such dislodgement is not usually fatal at this site.

\section{ACKNOWLEDGEMENTS}

This work was funded in part by a National Science Foundation grant OCE9985946 to M. W. Denny. This is contribution number 239 from PISCO, the Partnership 
for Interdisciplinary Studies of Coastal Oceans funded primarily by the Gordon and Betty Moore Foundation and the David and Lucile Packard Foundation. 


\section{REFERENCES}

Addy, T. C. \& Johnson, L. E. 2001. Littorine foraging behavior and population structure on a wave-exposed shore: non-linear responses across a physical gradient. Journal of Shellfish Research, 20, 385-391.

Bigler, E. 1964. Attrition on the Littorina planaxis population. Student paper, Hopkins Marine Station, Stanford University, Pacific Grove, CA, USA.

Blanchette, C. A. 1997. Size and survival of intertidal plants in response to wave action: a case study with Fucus gardneri. Ecology, 78, 1563-1578.

Bock, C. E. \& Johnson, R. E. 1967. The role of behavior in determining the intertidal zonation of Littorina planaxis Phillipi, 1847, and Littorina scutulata Gould, 1849.

Veliger, 10, 42-54.

Boulding, E. G. \& Van Alstyne, K. L. 1993. Mechanisms of differential survival and growth of two species of Littorina on wave-exposed and on protected shores. Journal of Experimental Marine Biology and Ecology, 169, 139-166.

Broekhuysen, G. J. 1940. A preliminary investigation of the importance of desiccation, temperature and salinity as factors controlling the vertical distribution of certain intertidal marine gastropods in False Bay, South Africa. Transactions of the Royal Society of South Africa, 28, 255-291.

Carrington, E. 1990. Drag and dislodgment of an intertidal macroalga: consequences of morphological variation in Mastocarpus papillatus Kutzing. Journal of Experimental Marine Biology and Ecology, 139, 185-200.

Carrington, E. 2002. The ecomechanics of mussel attachment: From molecules to ecosystems. Integrative and Comparative Biology, 42, 846-852.

Dayton, P. K. 1973. Two cases of resource partitioning in an intertidal community: making the right prediction for the wrong reason. The American Naturalist, 107, 662-670. Denny, M. W. 1987. Lift as a mechanism of patch initiation in mussel beds. Journal of Experimental Marine Biology and Ecology, 113, 231-245.

Denny, M. W. 1995. Predicting physical disturbance: mechanistic approaches to the study of survivorship on wave swept shores. Ecological Monographs, 65, 371-418. Denny, M. W. \& Blanchette, C. A. 2000. Hydrodynamics, shell shape, behavior and survivorship in the owl limpet Lottia gigantea. Journal of Experimental Biology, 203, 2623-2639.

Evans, F. 1961. Responses to disturbance of the periwinkle Littorina punctata (Gmelin) on a shore in Ghana. Proceedings of the Zoological Society of London, 137, 393-402. Garrity, S. D. 1984. Some adaptations of gastropods to physical stress on a tropical rocky shore. Ecology, 65, 559-574.

Gaylord, B., Blanchette, C. A. \& Denny, M. W. 1994. Mechanical consequences of size in wave-swept algae. Ecological Monographs, 64, 287-313.

Gendron, R. P. 1977. Habitat selection and migratory behaviour of the intertidal gastropod Littorina littorea (L.). Journal of Animal Ecology, 46, 79-92. 
Gochfeld, D. J. \& Minton, D. T. 2001. When to move and where to go: movement behavior of the tropical littorinid Cenchritis muricatus (Linnaeus, 1758). Journal of Shellfish Research, 20, 447-452.

Gowanloch, J. N. \& Hayes, F. R. 1926. Contributions to the study of marine gastropods I. The physical factors, behaviour, and intertidal life of Littorina. Contributions to Canadian Biology and Fisheries: Being Studies from the Biological Stations of Canada, 3, 135-165.

Hamilton, P. V. 1978. Intertidal distribution and long-term movements of Littorina irrorata (Mollusca: Gastropoda). Marine Biology, 46, 49-58.

Hamilton, P. V. \& Winter, M. A. 1982. Behavioural responses to visual stimuli by the snail Littorina irrorata. Animal Behaviour, 30, 752-760.

Kent, B. W. 1981. Feeding and food preferences of the muricid gastropod Ceratostoma foliatum. The Nautilus, 95, 38-42.

Land, M. F. \& Nilsson, D.-E. 2002. Animal Eyes. Oxford University Press, Oxford.

Lang, R. C., Britton, J. C. \& Metz, T. 1998. What to do when there is nothing to do: The ecology of Jamaican intertidal Littorinidae (Gastropoda: Prosobranchia) in repose. Hydrobiologia, 378, 161-185.

Lau, W. \& Martinez, M. 2003. Getting a grip on the intertidal: flow microhabitat and substratum type determine the dislodgement of the crab Pachygrapsus crassipes

(Randall) on rocky shores and in estuaries. Journal of Experimental Marine Biology and Ecology, 295, 1-21.

McMahon, R. F. \& Britton, J. C. 1985. The relationship between vertical distribution, thermal tolerance, evaporative water loss rate, and behavior on emergence in six species of mangrove gastropods from Hong Kong. P.^Pp. 563-582 in The Malacofauna of Hong Kong and Southern China. Ii, Vol. 1 and 2. Second International Workshop: Hong Kong, Hong Kong, Apr. 6-24, 1983., Morton, B. and Dudgeon, D., eds. Hong Kong University Press, Hong Kong.

McQuaid, C. D. 1981. The establishment and maintenance of vertical size gradients in populations of Littorina africana knysnaensis (Philippi) on an exposed rocky shore.

Journal of Experimental Marine Biology and Ecology, 54, 77-89.

Menge, B. A. 1976. Organization of the New England rocky intertidal community: Role of predation, competition, and environmental heterogeneity. Ecological Monographs, 46, 355-393.

Menge, J. L. 1974. Prey selection and foraging period of the predaceous rocky intertidal snail, Acanthina punctulata. Oecologia, 17, 293-316.

Newell, G. E. 1965. The Eye of Littorina littorea. Proceedings of the Zoological Society of London, 144, 75-86.

Norton, T. A., Hawkins, S. J., Manley, N. L., Williams, G. A. \& Watson, D. C. 1990.

Scraping a living: a review of littorinid grazing. Hydrobiologia, 193, 117-138.

Paine, R. T. 1988. Habitat suitability and local population persistence of the sea palm Postelsia palmaeformis. Ecology, 69, 1787-1794.

Pardo, L. M. \& Johnson, L. E. 2004. Activity and shelter use of an intertidal snail: effects of sex, reproductive condition and tidal cycle. Journal of Experimental Marine Biology and Ecology, 301, 175-191. 
Petraitis, P. S. 1982. Occurrence of random and directional movements in the periwinkle, Littorina littorea (L.). Journal of Experimental Marine Biology and Ecology, 59, 207217.

Raffaelli, D. G. \& Hughes, R. N. 1978. The effects of crevice size and availability on populations of Littorina rudis and Littorina neritoides. Journal of Animal Ecology, 47, 71-83.

Seyer, J.-O. 1992. Resolution and sensitivity in the eye of the winkle Littorina littorea. Journal of Experimental Biology, 170, 57-69.

Thain, V. M., Thain, J. F. \& Kitching, J. A. 1985. Return of the Prosobranch Gibbula umbilicalis (Da Costa) to the littoral region after displacement to the shallow sublittoral. Journal of Molluscan Studies, 51, 205-210.

Trussell, G. C. 1997. Phenotypic selection in an intertidal snail: Effects of a catastrophic storm. Marine Ecology Progress Series, 151, 73-79.

Underwood, A. J. \& McFadyen, K. E. 1983. Ecology of the intertidal snail Littorina acutispira Smith. Journal of Experimental Marine Biology and Ecology, 66, 169-197. Vermeij, G. J. 1971. Temperature relationships of some tropical Pacific intertidal gastropods. Marine Biology, 10, 308-314.

Wada, S. \& Ito, A. 2000. Preliminary observation on "tip-lip" attachment in the periwinkle Nodilittorina radiata. Bulletin of Marine Sciences and Fisheries Kochi University, 20, 15-24.

Warburton, K. 1973. Solar orientation in the snail Nerita plicata (Prosobranchia: Neritacea) on a beach near Watamu, Kenya. Marine Biology, 23, 93-100.

Warner, G. F. 2001. Trans-zonal movements in winkles, Littorina littorea (L.): reasons and consequences. Journal of Shellfish Research, 20, 495-499. 


\section{Figure legends:}

Figure 1 A representative granite promontory at Hopkins Marine Station. Littorina keenae may be found ranging up to the top of this structure, up to $5 \mathrm{~m}$ above Mean Lower Low Water. The rocks in the foreground are at approximately $1 \mathrm{~m}$ above MLLW. The arrow denotes the height at which littorines were collected for this study.

Figure 2 Average percent return of marked snails in each deployment. Numbers above each column denote offshore wave height during deployment. Error bars represent one standard deviation. 
Table 1. Total snails found alive following deployment on three dates.

\begin{tabular}{lllll}
\hline Deployment & Site & $\begin{array}{l}\text { \# Snails } \\
\text { Released }\end{array}$ & $\begin{array}{l}\text { \# Snail } \\
\text { Found Alive }\end{array}$ & \% Snails \\
& & Found Alive \\
\hline Oct 26 2004 & 1 & 50 & 28 & 56 \\
& 2 & 50 & 27 & 54 \\
Nov 8 2004 & 3 & 50 & 30 & 60 \\
& 1 & 50 & 33 & 66 \\
Feb 22 2005 & 2 & 50 & 44 & 88 \\
& 3 & 50 & 39 & 78 \\
& 2 & 49 & 32 & 65.3 \\
\hline Controls & 3 & 50 & 45 & 90 \\
\hline Feb 22 2005 & 1 & 24 & 39 & 78 \\
& 2 & 25 & 24 & \\
& 3 & 25 & 25 & 95.8 \\
\end{tabular}




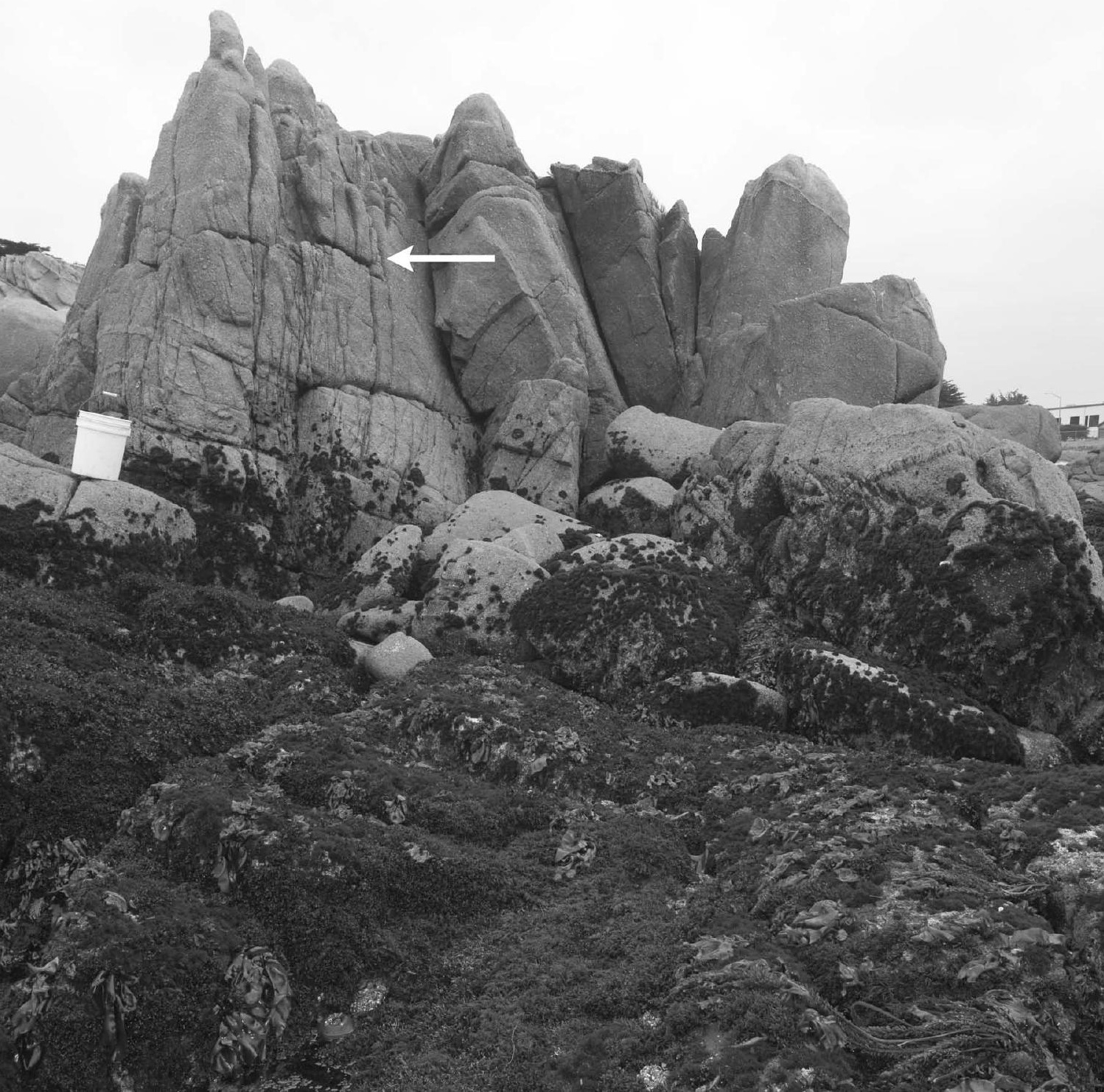




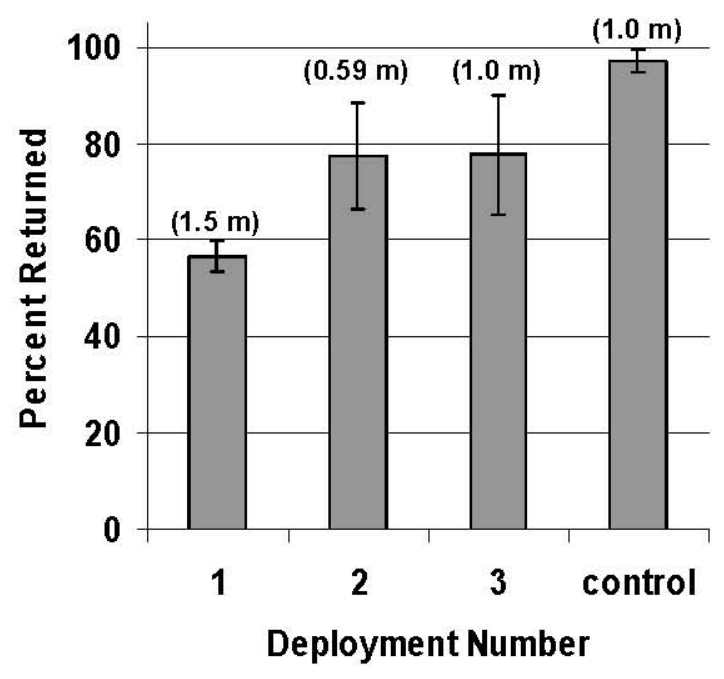

